\title{
CRTC1/MAML2 Fusion Gene
}

National Cancer Institute

\section{Source}

National Cancer Institute. CRT C1/MAML2 Fusion Gene. NCI Thesaurus. Code 199741.

A fusion gene ( $3.8 \mathrm{~kb})$ that results from a chromosomal translocation $\mathrm{t}(11 ; 19)(\mathrm{q} 14$ -

q21;p13-p12) which fuses exon 1 of the CRT 11 gene to exons 2-5 of the MAML2 gene.

This rearrangement is associated with mucoepidermoid carcinoma, Warthin's tumor and clear cell hidradenoma. 